\title{
THE ANTITRUST AND INTELLECTUAL PROPERTY INTERSECTION IN EUROPEAN UNION LAW
}

\author{
Nicolas Petit*

\section{INTRODUCTION}

In European legal scholarship, many articles discuss the equilibrium reached in the case-law of the Court of Justice of the European Union ("CJEU") when the EU antitrust prohibitions apply to, and restrain, the free and ordinary use of intellectual property rights ("IPRs"). ${ }^{1}$ We call this the antitrust-IP intersection.

The most interesting feature of this literature is perhaps the common assumption that a unifying substantive perspective, vision or theory on IPR underpins the intersection point reached by the antitrust case-law. Whilst the theory of "absolutism" can be quickly disposed of - it treats IPRs as statutory-crafted islands of monopoly in a sea of competition and grants IPR owners absolute freedom to exploit their rights without any risk of antitrust liability $-{ }^{2}$ several other theories are often advanced to rationalize the antitrust-IP intersection. The "theory of inherency" is one of them. Drexl explains that the theory of inherency "allow $[s]$ competition-law application only if the right is used to restrain competition outside the scope of the exclusive right". ${ }^{3}$ Dreyfus and Liannos write that it "protects the practices inherent to the exercise of the IP right from the

\footnotetext{
* Professor of Law, University of Liege, Belgium. Director of the Liege Competition and Innovation Institute (LCII), www.lcii.eu. I am grateful to D. Auer and J. Marcos Ramos for helpful comments on an earlier draft of this paper.

${ }^{1}$ This research is the by-product of the CJEU judgments, which often use abstract concepts and do not clearly articulate the elements of this supposed theory. Its judgments distillate an "it-is-so-because-we-says-so" approach, in the words of Antonin Scalia. See Webster v. Reproductive Health Servs., 492 U.S. 490, 552 (1989). A related doctrine is the limited license theory, whereby the fact that an IPR owner has granted a license on restrictive terms cannot give rise to antitrust liability, for the simple reason that the IPR owner could have instead decided not to provide a license.

${ }^{2}$ Käseberg, T. (2012), Intellectual Property, Antitrust and Cumulative Innovation in the EU and the US, Hart Studies in Competition Law, Hart Publishing at pp.25-26. The source of the island metaphor is impossible to trace, and is practically unhelpful. See Gosh, S. (2009). Carte Blanche, Quanta and Competition Policy, 34 Iowa J. CORP. L. 1209.

${ }^{3}$ We take this formulation from Drexl, J. (Ed.), Research Handbook on Intellectual Property and Competition Law, Max Planck Institute for Innovation and Competition, Munich, Germany, 2008, at p. 36.
} 
application of competition law". ${ }^{4}$

An alternative theory that some scholars and practitioners extract from the case-law is the "theory of exceptionalism" which says that antitrust liability for IPR related conduct can only be found in "exceptional circumstances". 5 The substantive foundations of exceptionalism are unclear, and can be traced to natural rights, utilitarianism or consequentialism. ${ }^{6}$ At a more pedestrian level, exceptionalism entails to set the rules of engagement of antitrust liability at a level that is, at least on paper, higher in IPR cases than in non IPR cases.

Lastly, the "theory of complementarity" ${ }^{7}$ views antitrust rules and IP protection as a complementary set of market institutions which converge towards a common goal. ${ }^{8}$ This view has become "mainstream" in recent years, ${ }^{9}$ and seems to be the one favored by policy makers. ${ }^{10}$ Its main implication is that ex post antitrust enforcement is never perceived as illegitimate when it seeks to correct certain ex ante defects of the IP

${ }^{4}$ Lianos, I. \& Dreyfuss, R.C. (2013). New Challenges in the Intersection of Intellectual Property Rights with Competition Law - A view from Europe and the United States. CLES Working Paper Series 4/2013.

${ }^{5}$ Ahlborn, C., Evans, D. S. \& Padilla, A. J. (2004). The Logic \& Limits of the 'Exceptional Circumstances Test' in Magill and IMS Health. Fordham International Law Journal, 28(4): 1108-1156; Heim, M. (2015). Observations on the Evolving Relationship between European Competition Policy and Patent Law. AIPLA 2015 Annual Meeting, Washington DC; Vesterdorf, B. (2013). IP Rights and Competition Law Enforcement Questions. Journal of European Competition Law \& Practice, 4(2), 109-111.

${ }^{6}$ Epstein, R.A. (2016). The Constitutional Foundations of Intellectual Property: A Natural Rights Perspective (Book Review). Federalist Society Review, Vol. 17, Issue 1.

7 The expression is used by Kolstad, O. (2008). Competition Law and Intellectual Property Rights - Outline of an Economics-based Approach in Drexl, J. (2008) op. cit., supra note 3 . He notes though that the two disciplines are not fully complementary, because despite their joint aim of dynamic efficiency (i) competition law primarily seeks to protect static efficiency and (ii) IP law (unlike competition law) also protects noneconomic goals.

${ }^{8}$ Anderman, S. D. (Ed.). (2007). The interface between intellectual property rights and competition policy. Cambridge University Press. Cohler, C. B., \& Pearson, H. E. (1994). Software Interfaces, Intellectual Property and Competition Policy. European Intellectual Property Review, 16, 434. Cohler \& Pearson note that "both policies protect a free market economy". See also Kolstad (2008) op. cit., note 6, "It can be argued that competition law and IP law share the same objectives".

${ }^{9}$ Czapracka, K. A. (2009). Intellectual Property and the Limits of Antitrust - A Comparative Study of US and EU Approaches, Edward Elgar; Czapracka, K. A. (2007). Where antitrust ends and IP begins-On the roots of the Transatlantic clashes. Yale Journal of Law \& Technology, 9, 44.

${ }^{10}$ Peeperkorn, L. and Paulis, E. (2005). Competition and Innovation: Two Horses Pulling the Same Cart in Lugard, P. and Hancher, L. (eds) (2005), On the Merits: Current Issues in Competition Law and Policy: Liber Amicorum Peter Plompen, Intersentia. 
system, ${ }^{11}$ and in particular when it attacks "improvidently defined IPRs". ${ }^{12}$

Against this backdrop, this paper is one of a legal realist. It submits that the antitrust-IP intersection does not rest on any unitary theory which, in turn, bespeaks the Court's vision of the social function of IPRs. ${ }^{13}$

Instead, the main feature of the CJEU case-law is that a specific methodology is applied to antitrust cases with IPR ramifications. The CJEU deals with most of such cases under a rule-based approach, as opposed to a standard-based approach. ${ }^{14}$ By rule-based approach, we refer to the ex ante setting of structured tests of liability or justifiability, by opposition to ex post case-by-case resolution on grounds of a predetermined, general standard (e.g., reasonableness, competition on the merits, efficiency, fairness, equity, etc.).

As will be seen below, this approach has many virtues, not least in terms of legal certainty. But it also has a major qualification. Whilst the Court has consistently formulated rules of liability and justifiability at the antitrust and IP intersection, it has at the same time often embedded abstract standards within those rules. The implications of this mixed approach are unclear.

To address those issues, this paper proceeds by elimination. We first show that the theory of inherency has not played a major role in the CJEU antitrust case-law (I). We then move on to track the prominence gained by the theory of exceptionalism in modern case-law. We demonstrate that it is a vacuous concept, devoid of substantive density (II). We turn then to the mainstream theory of complementarity, and find somewhat surprisingly that the EU Courts make little reference to it in their case law (III). We then pause for a short while to examine less influential theories which were rejected by the CJEU (IV). This brings us to our last section, which claims that the main systemic feature of the CJEU antitrust case-law in

\footnotetext{
${ }^{11}$ Ullrich H., Propriété intellectuelle, concurrence et régulation - limites de protection et limites de contrôle, Revue internationale de droit économique 2009/4 (t. XXIII, 4); Govaere I. \& Ullrich H. (eds.). (2008). Intellectual Property, Market Power and the Public Interest. Peter Lang, Brussels, 315 pp. College of Europe Studies. Vol. 8.

${ }^{12}$ Czapracka (2009), supra note 9.

13 Temple Lang makes a similar claim. He argues that "[t]he law has developed piecemeal without any explicit framework or general principle, and the Court has never explained the principles comprehensively". See, Lang, J. T. (2010, November). European competition law and intellectual property rights-a new analysis. ERA Forum (Vol. 11, No. 3, pp. 411-437). Springer-Verlag.

${ }^{14}$ For the difference between rules and standards, see Kaplow, L. (1992). Rules versus standards: An economic analysis. Duke Law Journal, 557-629. For a discussion in the antitrust field, see Posner, R. (2001). Antitrust Law, $2^{\text {nd }}$. Ed. The University of Chicago Press, at p.39.
} 
IPR cases may not be substantive, but methodological. In a significant proportion of the IP-related antitrust cases issued to date, the Court has almost invariably resorted to a rule-based approach, instead of a standardbased approach (V).

\section{INHERENCY}

The theory of inherency is an unconvincing rationalization of the antitrust-IP intersection. The point here is not that it does not exist in EU law. It does. Instead, it is that this theory has not exerted much influence in the review of antitrust allegations (as compared to other allegations of EU law infringements).

This can be seen in the treatment of inherency concept in early antitrust case-law. Whilst the EU Courts have introduced inherencycolored concepts like the "existence $v$ exercise" dichotomy or "specific subject matter" and "essential function" of IPRs (A), those concepts have mostly served rhetorical purposes in relation to antitrust allegations (B). Moreover, the irrelevance of those concepts has been precipitated in the modern era, with the EU Courts progressively phasing out any reference to them in its case-law (C). ${ }^{15}$

\section{A. Emergence of Inherency Concepts in Formative Case-Law}

A noteworthy feature of the early antitrust case-law of the EU Courts lies in the introduction of a number of inherency-related concepts which all seem to accept the existence of IPRs, and to limit antitrust intervention to certain residual acts of IPR owners which go beyond what is deemed to be reasonable.

The existence $\mathrm{v}$ exercise dichotomy is one of them. In Consten and Grundig $v$ Commission - the first antitrust infringement case ever decided by the Commission - the Court was invited to pass judgment on the antitrust-IP intersection. ${ }^{16}$ Grundig, a manufacturer of radio receivers, recorders, dictaphones and television sets, had granted exclusive territorial protection to Consten for the distribution of its products in France. ${ }^{17}$ In

\footnotetext{
${ }^{15}$ It is uneasy to provide a date for the beginning of what we call the modern era in EU competition law, but a possible starting point is early 2004, following the major institutional reform triggered by the adoption of Regulation 1/2003.

16 Ebb, L. F. (1967). The Grundig-Consten Case Revisited: Judicial Harmonization of National Law and Treaty Law in the Common Market. University of Pennsylvania Law Review, 115(6), 855-889.

${ }^{17}$ CJEU, Joined Cases 56 and 58/64, Etablissements Consten SARL and Grundig-
} 
addition, Grundig as the owner of an international trademark, had authorized Consten to register in France the trademark GINT (for Grundig International), so that Consten could block parallel imports of GINT labelled products coming from other countries. The Commission affirmed liability under Article 101 TFEU finding that the agreement between Grundig and Consten that authorized the later to register the GINT trademark under its own name was unlawful. ${ }^{18}$

On appeal, the Court confirmed in full the Commission's finding of infringement. On this occasion, it made a number of seminal substantive pronouncements which remain good law today. What may be less appreciated, however, is the CJEU dictum that the decision of the Commission could be deemed lawful because it did "not affect the grant of those rights but only limits their exercise to the extent necessary to give effect to the prohibition under Article 85 (1) [now Article 101(1) TFEU]". ${ }^{19}$ With this, the Court inaugurated the idea that competition law must operate on the basis of the inherently legitimate existence of IPRs.

This initial case paved the way to the development of an important stream of judgments where the Court invariably held that the "existence" of IPRs could not be affected by the prohibitions contained in Article 101 and 102 TFEU. Only the "exercise" of IPRs could, in contrast, come within the ambit of the antitrust rules. In what will later become a leitmotiv in the case-law, the Court repeated the existence $\mathrm{v}$ exercise dichotomy in relation to almost all forms IPRs, including patents (Parke Davis), ${ }^{20}$ copyrights (Deutsche Grammophon), ${ }^{21}$ designs (Keurkoop $v$ Nancy Kean Gifts), ${ }^{22}$ etc.

Verkaufs-GmbH v Commission, ECLI:EU:C:1966:41.

18 The Court found this agreement unlawful because it reinforced the exclusive territorial protection afforded to the retailer. A similar finding will be made in CJEU, 28/77, Tepea v Commission, ECLI:EU:C:1978:133, §44, where it will note that "the skillful use of trademark law has [...] strengthened the territorial protection given by the exclusive distribution agreement [...]".

${ }^{19}$ Id.: "[The] Articles [...] of the Treaty relied upon by the applicants do not exclude any influence whatever of Community law on the exercise of national industrial property rights"; and the contested decision "does not affect the grant of those rights but only limits their exercise to the extent necessary to give effect to the prohibition under Article 85 (1) [now Article 101(1) TFEU]".

${ }^{20}$ CJEU, 24/67, Parke, Davis \& Co. v Probel, Reese, Beintema-Interpharm and Centrafarm, ECLI:EU:C:1968:11, p.72: "the existence of the rights granted by a Member State to the holder of a patent is not affected by the prohibitions contained in Articles 85(1) and 86 of the Treaty."

${ }^{21}$ CJEU, 78/70, Deutsche Grammophon Gesellschaft mbH v. Metro-SB-Großmärkte GmbH \& Co. KG, ECLI:EU:C:1971:59, §\$6-7.

${ }^{22}$ CJEU, 144/81, Keurkoop v Nancy Keane Gifts, ECLI:EU:C:1982:289, §27: 
In other cases, the Court's carried the inherency language even further. In Parke Davis, the Court said that not any use of IPRs is potentially anticompetitive, but that it had to "degenerate" into an infringement. In Hoffmann-La Roche $v$ Centrafarm, it held that the exercise of trademarks was not unlawful in itself, unless the IPR was used as "an instrument for the abuse" of a dominant position. ${ }^{23}$

In parallel to the existence $\mathrm{v}$ exercise dichotomy, the CJEU further introduced other inherency-colored concepts in the antitrust case-law, like the concepts of "specific-subject matter" and of "essential functions" of IPRs. Enchelmaier defines them as follows: "while the specific subject matter tells us what owners of IPRs are allowed to do based on these rights, the essential function tells us the economic or other policy reasons why the legal system allows them to do so". ${ }^{24}$

Windsurfing is one of those cases. Here, the Commission had declared contrary to Article 101 TFEU several clauses of licensing agreements between Windsurfing who owned patents over some parts of sailboards, and sailboards manufacturers. The impugned agreements included a clause requiring prior approval by Windsurfing of the boards used by licensees as well as a non-challenge clause. In relation to both clauses, the Court noted that they did not fall within the "specific subject matter of the patent", and therefore confirmed that they constituted unlawful restrictions of competition. ${ }^{25}$

"Although a right to a design, as a legal entity, does not as such fall within the class of agreements or concerted practices envisaged by Article 85 (1), the exercise of that right may be subject to the prohibitions contained in the Treaty when it is the purpose, the means or the result of an agreement, decision or concerted practice."

${ }^{23}$ CJEU, 102/771, Hoffmann-La Roche v Centrafarm, ECLI:EU:C:1978:108, §16.

${ }^{24}$ Enchelmaier, S. (2010). Intellectual Property, the Internal Market and Competition Law in Drexl J. (ed.). Research handbook on Intellectual property and Competition law. Edward Elgar Publishing, 2010, at p.411. Helen Norman provides also a definition: "each form of intellectual property has a 'specific subject matter' and an 'essential function'. In relation to patents, the 'essential function' is to reward creativity, whilst the 'specific subject matter' is to allow the proprietor the exclusive right to use the invention to make industrial products". See Norman, H. (2011). Intellectual Property Law Directions. Oxford University Press, at p.412.

${ }^{25}$ CJEU, Case 193/83, Windsurfing International v Commission, ECLI:EU:C:1986:75, $\S 45$ in relation to quality controls and $\$ 92$ in relation to the non challenge cause: "clearly does not fall within the specific subject-matter of the patent, which cannot be interpreted as also affording protection against actions brought in order to challenge the patent's validity, in view of the fact that it is in the public interest to eliminate any obstacle to economic activity which may arise where a patent was granted in error." 


\section{B. Operational Irrelevance of Inherency Concepts in Formative Case-Law}

One claim that is often encountered is that the abovementioned inherency concepts have played (and still play) a role in the antitrust case law of the CJEU. For instance, Korah has written that "the [CJEU] looks to the specific subject matter of the particular kind of IPR when applying not only the rules for free movement, but also the competition rules". ${ }^{26}$

This position cannot be sustained. ${ }^{27}$ If they really had operational relevance, the protective inherency concepts should have resulted in exoneration of antitrust liability in a significant number of cases. On the contrary, in most of the cases where the Court had to decide on the merits of the competition allegations, it affirmed liability.

The literature also occasionally obscures the point that the case-law on "specific-subject matter" and "essential function" is not, in reality, competition case-law. Whilst it is true that the cases in discussion certainly involved allegations of competition law infringements, those allegations were systematically preceded by allegations of violations of the free trade provisions of the EU Treaties. And it is during the review of those allegations that the Court employed the inherency concepts, arguably to soothe Member States concerns over the division of competence between the EU and its Member States. ${ }^{28}$

Lastly, in the rare cases where the inherency concepts were put to practice, they proved very poor at guiding the antitrust inquiry, and in particular at discriminating between antitrust-reprehensible and antitrustimmune conduct. This can be seen by comparing two cases, ie Sirena and EMI v CBS. In Sirena, a US producer of cosmetic and medicinal cream had assigned trademark rights to distinct manufacturers in Germany and Italy. ${ }^{29}$

${ }^{26}$ See Korah, V. (2006) Intellectual Property Rights and the EC Competition Rules, Hart Publishing, at p. 125: "the ECJ looks to the specific subject matter of the particular kind of IPR when applying not only the rules for free movement, but also the competition rules"

${ }^{27}$ Korah, herself, has seemed to doubt it. In a 2001 paper, she wrote that the existence and exercise dichotomy was a "metaphysical distinction". Korah, V. (2001). The Interface between Intellectual Property and Antitrust: The European Experience. Antitrust Law Journal, 2001, Vol. 69, 801, at p.805.

${ }^{28}$ See Lianos \& Dreyfuss (2013) supra note 4.

${ }^{29}$ CJEU, 40/70, Sirena v EDA, ECLI:EU:C:1971:18, §9. “A trade-mark right, as a legal entity, does not in itself possess those elements of contract or concerted practice referred to in Article 85 (1). Nevertheless, the exercise of that right might fall within the ambit of the prohibitions contained in the Treaty each time it manifests itself as the subject, the means or the result of a restrictive practice. When a trade-mark right is exercised by virtue of assignments to users in one or more Member States, it is thus necessary to establish in each case whether such use leads to a situation falling under the prohibitions 
The Italian manufacturer had sought to rely on the trademark to restrict imports of the German-made cream on domestic territory. The CJEU held that Article 101 TFEU was applicable to the extent to which "trademarks were invoked so as to prevent imports of products" across distinct Member States. ${ }^{30}$ Several years later, the Court reversed this case-law in EMI $v$ $C B S,{ }^{31}$ insisting on the proof of an additional agreement or concerted practice for a finding of Article 101 TFEU liability, and stressing that the "mere exercise of the national trade mark rights" could not be akin to an infringement. ${ }^{32}$

With this background, the rationalization of the early case-law on the antitrust-IP intersection as inherency spirited resembles to a legal fable. ${ }^{33}$ The inherency concepts appear mostly to have been used as prose introduced in judgements to dispel concerns of antitrust activism in IPRrelated matters. ${ }^{34}$ Instead, the formative era pictures the Court stepping over the very existence of IPRs in several cases. In Windsurfing International for instance, the Court held that "although the Commission is not competent to determine the scope of a patent, it is still the case that it may not refrain from all action when the scope of the patent is relevant for the purposes of determining whether there has been an infringement of [101] and [102 TFEU]". ${ }^{35}$ And in Sirena, the Court daringly affirmed that the public interest protected by trademarks is lower than that protected by other IPRs. ${ }^{36}$

\section{Phasing Out of Inherency Concepts in Modern Case-Law}

Dreyfus and Liannos argue that since the Court's 1982 decision in Coditel II, the existence $v$ exercise dichotomy has never featured as an

of Article 85".

${ }^{30} I d ., \S 11$.

${ }^{31}$ CJEU, 86/75, EMI Records Limited v. CBS Grammofon A/S, ECLI:EU:C:1976:86.

${ }^{32} I d$., $\S \$ 24-29$.

33 See Lianos \& Dreyfuss (2013) supra note 4.

${ }^{34}$ As Korah rightly notes in relation to the exercise $\mathrm{v}$ existence dichotomy, those concepts are elusive: "the existence of a right comprises all the ways in which it may be exercised". See Korah (2006) supra note 26, at p. 3.

${ }^{35}$ CJEU 193/83, Windsurfing International v Commission, ECLI:EU:C:1986:75, §26.

${ }^{36}$ CJEU, 40/70, Sirena v EDA (cit. note 27). In the case, AG Dutheillet de Lamothe had advised the Court that trademarks did not merit special respect because they are "nothing more than an aid to advertising". (C-40/70, Sirena v Eda, ECLI:EU:C:1971:3, p.87). At $\$ 7$ the Court will follow this reasoning, though less explicitly, noting: "Moreover, a trade-mark right is distinguishable in this context from other rights of industrial and commercial property, inasmuch as the interests protected by the latter are usually more important, and merit a higher degree of protection, than the interests protected by an ordinary trade-mark". 
important element of the Court's reasoning in competition cases involving IP rights. ${ }^{37}$ This finding is not entirely right, at least time wise. In 1988 the Court held in $A B$ Volvo and Erik Veng that a car manufacturer could lawfully refuse to grant licenses of its design rights on car parts, even in exchange for a reasonable royalty. In turn, the Court hammered again to that the "exercise" of this exclusive right could be prohibited by Article 102 TFEU, if it involves "certain abusive conduct".

That said, Dreyfus and Liannos' point is certainly valid in relation to the other inherency concepts. ${ }^{38}$ The seminal Magill case of 1995 best evidences this. At issue was the conduct of British and Irish TV channels, who had relied in parallel on their respective copyrights over weekly schedules to prevent a third party from editing a novel, comprehensive TV magazine covering all channels' programmes. The Commission found an infringement of Article 102 TFEU. On appeal, the General Court upheld the Commission's reasoning, relying heavily on the inherency notion of "essential function". It held in particular that the channels conduct went "beyond what it necessary to fulfil the essential function of the copyright as permitted in Community law". 39

The judgment was further appealed before the CJEU. During the proceedings, Advocate General Gulmann used the inherency concepts to advise the Court to vacate the appeal. He noted that "the right to refuse licences forms part of the specific subject matter of copyright". ${ }^{40}$ And he further lambasted the General Court for its failure to extend antitrust

37 Lianos and Dreyfuss (2013) supra note 4, at p.55. In Coditel II, the Court affirmed "Although copyright in a film and the right deriving from it, namely that of exhibiting the film, are not, therefore, as such subject to the prohibition contained in Article 85, the exercise of those rights may, none the less, come within the said prohibitions where there are economic or legal circumstances the effect of which is to restrict film distribution to an appreciable degree or to distort competition on the cinematographic market". See CJEU, C-262/81, Coditel v Ciné-Vog Films, ECLI:EU:C:1982:334, §17.

${ }^{38}$ Already in the Windsurfing judgment of 1983, the Court made no reference to the existence $v$ exercise dichotomy to hold that a patent holder has unlawfully introduced restrictive clauses in its licensing agreements with sailboards manufacturers. As seen above, the Court relied more predominantly on the concept of "specific subject matter", though to support a finding of liability. CJEU, 193/83, Windsurfing International Inc. $v$ Commission (cit. note 33).

${ }^{39}$ GC, T-69/89, Radio Telefis Eireann v. Commission, ECLI:EU:T:1991:39, §73: "goes beyond what it necessary to fulfil the essential function of the copyright as permitted in Community law".

${ }^{40}$ Opinion of Advocate General Gulmann in Joined cases C-241/91 P and C-242/91 P, Radio Telefis Eireann (RTE) and Independent Television Publications Ltd (ITP) $v$ Commission, ECLI:EU:C:1994:210, $§ 38$ and 70. 
immunity to conduct falling within the scope of the "essential function of copyright" ${ }^{41}$

In its final determination, the CJEU took a different tack, and refused to review the case through the "specific subject matter" and/or "essential function" of copyrights. ${ }^{42}$ Instead, the judgment soberly stated that "the exercise of an exclusive right by the proprietor may, in exceptional circumstances, involve abusive conduct". ${ }^{43}$ As Czapracka rightly observes, proceeding on the basis of the specific subject matter would have restricted the Court's ability to hold the TV channels liable of an abuse, as the TV channels had strictly behaved as ordinary IP owners. ${ }^{44}$

In retrospect, Magill signed the death knell of inherency concepts in antitrust case-law. As will be seen in the next section, no judgment of the CJEU has since then relied on "specific subject matter" or "essential function" as a decisive parameter of antitrust liability. Instead, the Court has embraced a novel concept of "exceptional circumstances", whose relevance now deserves to be discussed.

\section{EXCEPTIONALISM}

Several authors consider that the antitrust-IP intersection is governed by a theory of "exceptionalism". Under this theory, the exercise of IPRs is deemed presumptively lawful under the antitrust provisions, save in "exceptional circumstances". With this, the rules of engagement of antitrust liability are allegedly set at a level that is higher than in non-IPR cases. The theory of exceptionalism would have been the one followed by the CJEU and the lower courts in most antitrust cases with IP ramifications since Magill, though with variations. In the following sections, we track the evolution of this theory since Magill (A), and discuss whether it is indeed the theory that today governs the antitrust-IP intersection (B). We conclude with a discussion on the scholarly interpretation of the meaning of exceptionalism (C).

41 This paragraph draws from the analyzis found in Lianos and Dreyfuss (2013) excellent paper, supra note 4 , at p.55.

${ }^{42} I d$.

43 CJEU, C-241/91 and C-242/91, RTE and ITP Ltd $v$ Commission, ECLI:EU:C:1995:98. This point is also stressed in Lianos and Dreyfuss (2013) supra note 4, p.55.

${ }^{44}$ Czapracka (2007) supra note 9. This was actually the approach encouraged by Advocate General Gulmann, who had advised the Court to reject antitrust liability, on the ground that the TV channels had stayed with the specific subject matter of their right. This may explain that the Court strayed from the early restrictive concepts. 


\section{A. Cases}

The novel concept of "exceptional circumstances" introduced in Magill was not immediately picked upon by the lower courts, and a period of fluctuation appeared at the General Court level. In the 1997 Tiercé Ladbroke SA v Commission judgment, the GC refused to discuss the existence of "exceptional circumstances", despite the fact that the dispute concerned very similar allegations, namely that a French horse trading company had refused to license its copyrights over televised pictures and sound commentaries of French races to Ladbroke, whose business consisted in operating horse betting outlets in Belgium. ${ }^{45}$ The Court confirmed the Commission's decision to reject Labroke's complaint, and noted that Magill was highly specific, and limited to scenarios of anticompetitive leveraging where the dominant firm also exploits the IPRs, and uses them to harm competitors. ${ }^{46}$ Two years later, the General Court will however endorse Magill's "exceptional circumstances" in Micro Leader Business v Commission. The case focused on Microsoft's attempts to restrict Canadian wholesalers from exporting copyrighted computer software towards the EU. The GC stressed that Microsoft could lawfully enforce its copyrights in Europe in order to prevent imports of products first sold in Canada. ${ }^{47}$ However, it added obiter dictum, and quoting Magill, that: "[it is clear from the case-law that whilst, as a rule, the enforcement of copyright by its holder, as in the case of the prohibition on importing certain products from outside the Community in to a Member State of the Community, is not in itself a breach of Article 86 [now 102 TFEU] of the Treaty, such enforcement may, in exceptional circumstances, involve abusive conduct (emphasis added)". ${ }^{48}$

In the next case to reach the EU Courts docket, the CJEU made clear that the concept of "exceptional circumstances" introduced in Magill was not a passade. In IMS Health, a marketing data firm had designed a very granular map which could be used by stakeholders of the pharmaceutical industry to track sales over the German territory. The map soon became

\footnotetext{
${ }^{45}$ This point is also made by Czapracka (2007) who notes that Ladbroke is loser than IMS Health, supra note 9, at p.85.

${ }^{46}$ See GC, T-504/93, Tiercé Ladbroke SA v Commission, ECLI:EU:T:1997:84, §130: "The applicant cannot rely on the Magill judgment to demonstrate the existence of the alleged abuse, since that decision is not in point". In reality, "in the absence of direct or indirect exploitation by the sociétés de courses of their intellectual property rights on the Belgian market, their refusal to supply cannot be regarded as involving any restriction of competition on the Belgian market".

${ }^{47}$ For this would remain consistent with the principle of European exhaustion.

${ }^{48}$ See GC, T-198/98, Micro Leader Business v Commission, ECLI:EU:T:1999:341, $\S \S 34$ and 56.
} 
an industry standard, not least because it had been developed in cooperation with the pharmaceutical industry. When a former employee of IMS Health set up a new marketing data company ("NDC"), and designed its own competing map, he did not manage to attract clients for most prospective users were accustomed to IMS Health maps. NDC thus proceeded to use IMS Health's type of maps. A dispute unravelled. IMS Health, which held copyrights over the maps, sought and obtained a prohibitory injunction against NDC before the German courts. NDC reciprocated by launching antitrust proceedings before the Commission alleging that IMS Health was guilty of abusive refusal to supply. The Commission affirmed liability, but the operation of the Commission's decision was suspended on appeal. In parallel, as the initial injunctive relief case moved through the German appeals system, a preliminary reference was eventually sent to the CJEU.

The wording of the judgment leaves no shred of a doubt on the Court's resolve to cement the Magill case-law. Quoting Magill, the Court held generally that "exercise of an exclusive right by the owner may, in exceptional circumstances, involve abusive conduct". ${ }^{49}$ This statement is not specifically cantoned to refusals to license. In fact, the Court quotes as further authority a paragraph of $A B$ Volvo and Erik Veng where it is said that pricing levels of IPR protected goods can fall foul of Article 102 TFEU. All this notwithstanding, what is perhaps more important in IMS Health is however not explicit in the judgment. In the scholarship, some had hewed to the view that Magill was confined to its own facts, and that the main driver behind the finding of antitrust liability was to correct an anomaly in Irish IP law, namely that ludicrous IPRs could be improvidently granted for TV schedules. ${ }^{50}$ IMS Health proved this reading wrong. Magill was not an anecdotal judgment. Unlike in Magill, where the IPRs in question might have seemed improvidently awarded, the IPRs in dispute were ordinary garden variety. ${ }^{51}$

Since IMS Health, two sets of cases have seemed to further the theory of "exceptionalism". First, exceptionalism has been the approach ordinarily followed in refusal to license cases, not least in the Microsoft I and II judgments of the General Court where it was held that Microsoft had unlawfully withheld essential interoperability information from rivals,

\footnotetext{
${ }^{49}$ See CJEU, C-418/01 IMS Health, ECLI:EU:C:2004:257, §35.

${ }^{50}$ Korah, V. (2001) supra note 26 (writing that "In Magill, the intellectual property rights were wider than are usually granted in Europe or elsewhere"). Czapracka (2009) supra note 9 , at p.47, in particular footnote 44 .

${ }^{51}$ See CJEU, IMS Health, supra note 49, $\$ 22$. The Court noted that the case was based on the assumption that IMS Health maps are protected by an IPR.
} 
in a bid to leverage its dominant position on the market for Operating Systems ("OS") for PCs towards the adjacent market for work group servers OS. ${ }^{52}$ In the two Microsoft cases, the General Court cases recalled that such exceptional circumstances were met, even though Microsoft I promoted a somewhat controversial interpretation of Magill and IMS Health. ${ }^{53}$

Second, the theory of exceptionalism has also been applied to IP remedy cases. In Protégé International $v$ Commission, ${ }^{54}$ Pernod Ricard SA, who owned the "Wild Turkey" trademark for whiskey, had commenced opposition proceedings with several trademark offices upon learning that Protégé International had applied for the registration of the "Wild Geese" trademark for whiskey. Protégé International reciprocated by lodging an antitrust complaint with the EU Commission, alleging that the initiation of opposition proceedings by Pernod Ricard SA was an anticompetitive abuse. The Commission dismissed the complaint, and the General Court affirmed. It observed that because access to justice is a fundamental right, it is only in "wholly exceptional circumstances" that the pursuit of legal remedies - including on the basis of IPRs can be deemed abusive. In the GC's view, such circumstances are present when the proceedings cannot be "considered as an attempt to establish its rights and can therefore only serve to harass the opposite party"; and (ii) are conceived as a "framework of a plan whose goal is to eliminate competition". ${ }^{55}$

\section{B. Is the Antitrust-IP Intersection Governed by the Theory of Exceptionalism?}

With this background, the following sections seek to understand if the theory of exceptionalism can be deemed to be the lynchpin of the antitrustIP intersection in modern competition law. The evidence is mixed. We expose hereafter validating (1) and invalidating arguments (2).

\footnotetext{
${ }^{52}$ See GC, T-201/04, Microsoft v Commission (Microsoft I), ECLI:EU:T:2007:289, §31: "It is only in exceptional circumstances that the exercise of the exclusive right by the owner of the intellectual property right may give rise to such an abuse". GC, T-167/08, Microsoft Corp. v Commission (Microsoft II), ECLI:EU:T:2012:323, §§139-140 (though the GC does not explicitly mentions exceptional circumstances, it rules that the IMS Health conditions were fulfilled in Microsoft I).

${ }^{53}$ See the discussion below and Fox, E. (2008). Microsoft (EC) and Duty to Deal: Exceptionality and the Transatlantic Divide. CPI Journal, 2008, vol. 4.

${ }_{54}$ See GC, T-119/09, Protégé International Ltd $v$ European Commission, ECLI:EU:T:2012:421.

${ }^{55} I d ., \$ 49$.
} 


\section{Yes}

The 2012 judgment of the CJEU in AstraZeneca $v$ Commission corroborates particularly well the hypothesis that the theory of exceptionalism is the lynchpin of the antitrust-IP intersection. ${ }^{56}$ This judgment is often - and understandably - overlooked in the antitrust and IP literature because the impugned conduct did not involve an IP-instrumented strategy. This notwithstanding, AstraZeneca $v$ Commission makes important dicta on the antitrust-IP intersection. The AstraZeneca Court had to review previous decisions that had held a dominant drug manufacturer liable of unlawful abusive tactics aimed at delaying generics competition. Amongst other things, the dominant firm had acted before three national agencies to obtain deregistration of its marketing authorisations over capsules of its blockbuster drug Losec. In turn, the dominant firm had withdrawn all existing Losec capsules from those markets, and launched Losec in tablet format. The Commission found, and the General Court confirmed, that those measures sought to prevent rival generic manufacturer to rely on the marketing authorization to speedily release Losec capsules.

In the course of the proceedings, AstraZeneca sought to draw an analogy with the IMS Health case, and argued that it is only in "exceptional circumstances" that its statutory right to free deregistration could be undermined by Article 102 TFEU. ${ }^{57}$ With this, AstraZeneca hoped to have the Court declare that the Commission and the General Court had applied an insufficiently stringent liability test.

The Court dismissed AstraZeneca's claim, and confirmed the Commission and General Court's findings of unlawful abuse. However, an often-missed point is that the Court's judgment unequivocally endorsed the exceptionalism hypothesis. The reasoning is convoluted, yet the point is clear. The Court first held that antitrust law can bring limitations to the exercise of a statutory-granted right to deregistration, and that a finding of

${ }^{56}$ See CJEU, C-457/10, AstraZeneca v Commission, ECLI:EU:C:2012:770.

57 Id., §142: "The appellants maintain that the General Court erred in law in considering that the conduct impugned in the context of the second abuse tended to restrict competition. They argue that the mere exercise of a right lawfully afforded by Union law could at the most amount to an 'abuse' only in exceptional circumstances, namely where there is an elimination of all effective competition, a mere propensity to distort competition not being sufficient for that purpose. An analogy should be drawn with compulsory licensing cases, such as that dealt with in Case C-418/01 IMS Health [2004] ECR I-5039. That analogy is justified by virtue of the 'effective expropriation' of the right to request deregistration of the MA and by virtue of the fact that the prohibition on deregistration is a form of compulsory licensing". 
abuse under such circumstances is in no way an "exceptional case". ${ }^{58}$ The Court then moved on to add an important statement: the situation in the case at hand "does not justify a derogation from Article [102 TFEU], unlike a situation in which the unfettered exercise of an exclusive right awarded for the realisation of an investment or creation is limited". ${ }^{59}$ What this means does not deserve long explanation. The Court mutters that IPRs - it talks of "exclusive rights" - are subject to a derogatory regime under Article 102 TFEU. Their "unfettered exercise", says the Court implicitly, can only be restricted in "exceptional" cases. And this is due to the fact that they are the reward of an investment of creation, unlike the right to deregistration.

Upon review of the Court's entire antitrust case-law, we believe that no judgment better than AstraZeneca $v$ Commission carries the theory of exceptionalism. The wording of the judgment - which we suppose was carefully chosen by the judges - is not circumscribed to refusal to license or IP remedies, and talks generally of the "exercise of an exclusive right".

In the literature, some scholars consider that exceptionalism is the transversal principle behind the antitrust-IP intersection, at least in so far as Article 102 TFEU is concerned. Anderman and Schmidt note that "Broadly, one can talk of an 'exceptional circumstances' test under Article [102 TFEU], which operates to limit its application to the exercise of IPRs quite explicitly in the case of the abuse of refusal to supply and implicitly in the case of the abuse of excessive pricing" ${ }^{60}$ Further, they observe that "both the language of Article [102 (b) TFEU] and the [EU] judgment in IMS offer good grounds for concluding that other types of abuses can also fall within the category of "exceptional circumstances".

2. No

At the same time, other contemporary pronouncements of the EU Courts seem to discredit the claim that the theory of exceptionalism is the lynchpin of antitrust jurisprudence in IPR cases. We review the various arguments in turn.

a. Exceptionalism is not IPR-specific

The theory of exceptionalism is not an idiosyncrasy of the IPR-related antitrust case-law. On the contrary, the theory of exceptionalism is the one

${ }^{58} I d ., \S 150$.

${ }^{59} \mathrm{Id}$.

${ }^{60}$ Anderman, S.D and Schmidt, H. (2007). EC competition policy and IPRs, in Anderman (2007) supra note 8, at 41. 
conventionally applied in all refusal to deal cases, regardless of whether the asset to which the dominant firm refuses access is IPR-protected or not. In Bronner v Mediaprint, the Court's seminal case on refusal to deal cases, the Court applied the concept of "exceptional circumstances" previously affirmed in Magill to a situation where a dominant firm had refused access to a pedestrian facility, namely a distribution system for daily newspapers. ${ }^{61}$

Similarly, the concept of "wholly exceptional circumstances" found in Protégé International v Commission is not a specificity of IPR remedy cases. The General Court had previously applied this strict version of the theory of exceptionalism in ITT Promedia, a case where the Belgian telecoms incumbent had sought ordinary judicial remedies against a publisher of directories that had used its non-IPR-protected subscriber data. $^{62}$

b. Exceptionalism is not systemic in the IPR antitrust law

If the theory of exceptionalism were the regulating concept of the antitrust-IP intersection, then one would expect to observe it in all IPRrelated cases. However, in the high profile DSD case of 2009, the Grand Chamber of the Court dispensed with laboring "exceptional circumstances". In dispute was whether DSD, a dominant German waste collection system, had committed an abuse by requiring from its customers the payment of a fee for all packaging bearing its trademark, even if those customers had not used DSD collecting service. The Court affirmed antitrust liability, and made no single reference to "exceptional circumstances". ${ }^{63}$ Instead, the Court framed the case as a conventional exploitative abuse case, and referenced non-IP precedents in support of its reasoning.

In addition to this, the theory of exceptionalism has mostly been used in abuse of dominance cases, and comparatively little, if not, in anticompetitive coordination cases. ${ }^{64}$

${ }^{61}$ CJEU, C-7/97, Bronner v Mediaprint, ECLI:EU:C:1998:569, §26 notably, "[t]hus, as the Court expressly held in Magill, an obligation to contract, to which an undertaking holding a dominant position would be subject, can be based on Article 86 of the Treaty only in exceptional circumstances". Since Bronner v Mediaprint, all refusal to deal cases stress that antitrust liability can only arise in the presence of "exceptional circumstances".

${ }^{62}$ See GC, T-111/96, ITT Promedia NV v Commission, ECLI:EU:T:1998:183, §60. The case was also about the allegedly excessive price charged by Belgacom.

63 See CJEU, C-385/07 P, Duales System Deutschland $v$ Commission, ECLI:EU:C:2009:456, §143: "the conduct of [Duales System Deutschland] DSD which is objected to in Article 1 of the decision at issue and which consists in requiring payment of a fee for all packaging bearing the DGP logo and put into circulation in Germany, even where customers of the company show that they do not use the DGP system for some or all of that packaging, must be considered to constitute an abuse of a dominant position".

${ }^{64}$ Anderman picks up the question in relation to IP licensing: "To what extent does competition policy provide special protection in this sphere analogous to the exceptional 
Surely, this discrepancy may be explained by the dearth of IPR related Article 101 TFEU cases in recent years, which in turn originates in a variety of reasons. ${ }^{65}$ Interestingly, the Commission implicitly rebuffed the applicability of the theory of exceptionalism under Article 101 TFEU in its infringement decision in Lundbeck. ${ }^{66}$ With patent settlement agreements in sight, it held that "[s]uch agreements are fully subject to the discipline of competition law". ${ }^{67}$ And it added that "this also applies to agreements whose purpose is to put an end to or otherwise deal with patent litigation or, more broadly, patent disputes". ${ }^{68}$ This broad conception remains to be scrutinized by the EU courts, but it suggests that the limiting principles of the Article 102 TFEU case-law may not apply in the anticompetitive coordination space.

c. Exceptionalism and particularism?

In Huawe $̈ v$ ZTE, the CJEU introduced a novel possibility to find antitrust liability under Article 102 TFEU in the presence of "particular circumstances". ${ }^{69}$ In the case in point, the legal issue was whether the holder of a patent that has been declared essential to a collaborative technology standard ("SEPs"), and which it has pledged to license on Fair, Reasonable and Non-Discriminatory ("FRAND") terms, could be deemed guilty of unlawful abuse when it applies for a court injunction and/or product recall against unlicensed implementers of its technology.

The Court held that such conduct could be deemed abusive not in "exceptional", but in "particular circumstances", presumably recognizing that the facts before it could not properly be considered as "exceptional" given the widespread nature of patent disputes in standardized industries. ${ }^{70}$

circumstances' test of Article 82?" without, however, providing an answer. See Steve Anderman, (2008). The new EC competition law framework for technology transfer and IP licensing' in Drexl (2008) supra note 3, at p.109.

${ }^{65}$ Anderman in Drexl (2008) identifies several reasons (see supra note 64). In his view, the Nungesser case-law, which treats licensing restrictions as ancillary has laid down an IP friendly context for licensing agreements. The case law on exhaustion has limited the risk of IP strategies as a market division practice. And the abolition of the notification of agreements to the Commission may also have dried up the amount of Article 101 cases to reach the Court's docket.

${ }^{66}$ The Commission devoted a full section to "patents and competition law". See Commission Decision, Case AT.39226 - Lundbeck, C(2013) 3803 final (19.06.2013), $\S \S 598$ and following.

${ }^{67} \mathrm{Id}$., at $\$ 600$.

${ }^{68} \mathrm{Id}$.

${ }^{69}$ CJEU, C-170/13, Huaweï v ZTE, ECLI:EU:C:2014:2391, §48.

70 Rato, M., \& English, M. (2016). An Assessment of Injunctions, Patents, and Standards Following the Court of Justice's Huawei/ZTE Ruling. Journal of European Competition Law \& Practice, 7(2): 103-112. 
Such particular circumstances could be deemed to occur, according to the Court, when (i) the patent at issue is "essential ... rendering its use indispensable to all competitors which envisage manufacturing products that comply with the standard [...]"; and (ii) the SEP holder has given an "irrevocable undertaking [...] to the standardisation body in question, that it is prepared to grant licences on FRAND terms". ${ }^{71}$

In the scholarship, some practitioners have argued that Huaweï v ZTE sets a "different standard" which strays from the theory of exceptionalism. ${ }^{72}$ However, the same authors concede that the new concept "resemble[s] the 'exceptional circumstances' of the conventional case law", so that Huaweï v ZTE may be seen as the progeny of Magill and IMS Health. This impression is further supported by the case-law cited by the Court, which refers to Volvo, Magill and IMS Health. ${ }^{73}$

That said, the right reading is in our view that Huaweï $v$ ZTE sets a new rule of engagement of Article 102 TFEU liability that is distinct from the theory of exceptionalism. As the Court explicitly affirms "the particular circumstances of the case in the main proceedings distinguish that case from the cases which gave rise to the case-law" in Volvo, Magill and IMS Health. ${ }^{74}$ The Court's reference to the conventional case-law is a formal trick. As is well known, the CJEU hates to explicitly admit that it adapts, improves, or reverses conventional case-law. What Huaweï v ZTE thus confusingly suggests is that the theory of exceptionalism is not the whole and sole threshold for the engagement of antitrust liability against IPR strategies.

d. Open-ended content of exceptionalism?

We believe that there is one last argument which flouts the idea that the theory of exceptionalism is the lynchpin of the antitrust-IP intersection. The concept of "exceptional circumstances" has been interpreted in the case-law to be open-ended, in violation of the general principle of law that exceptions ought to be interpreted restrictively. ${ }^{75}$ As a result, if the theory

${ }^{71}$ CJEU, Huaweï v ZTE supra, note 69, §59.

${ }^{72}$ See Rato \& English (2016) supra note 70, at p.107: "In the present ruling, the CJEU may have recognised that the facts before the Court did not fit into the established case law and that the circumstance could not properly be considered as 'exceptional' However, rather than concluding that there was therefor no room to find abusive conduct, the CJEU adopted a different standard of "particular circumstances".

${ }^{73} I d . \$ \$ 46-47$.

${ }^{74} I d ., \S 48$.

${ }^{75}$ Dreyfuss and Lianos (2013) supra, note 4, at p.81: "[t]he interpretation of the case law and in particular the decisional practice of the Commission and its soft law rule making activity indicate, however, that these "exceptional circumstances" have been 
of exceptionalism exists as a formal legal construct, its scope seems so elusive that its substantive value can be called into question.

Antitrust savvy readers will recall that in IMS Health, the CJEU had considered that the presence of three market circumstances was "sufficient" to create "exceptional circumstances", ie that the refusal to license (i) prevents the emergence of a new product; (ii) has no objective justification; and (iii) eliminates all competition on a secondary market. ${ }^{76}$ During the pleadings of the Microsoft case, the Commission took the CJEU judgment on the word and argued that the "exceptional circumstances" found in IMS Health were not exhaustive. Accordingly, proof of the three criterion designated in IMS Health was not a necessary requirement. The Commission conceivably understood that the main weakness of its case was that it had not established that Microsoft's withholding of interoperability information had prevented the launch of new products. The General Court backed the Commission, contemplating the possibility to assess other "particular circumstances" if "one or more of those circumstances [identified in Magill and IMS Health] are absent". ${ }^{77}$ This notwithstanding, the GC found that "the circumstance relating to the appearance of a new product [was] present in this case". ${ }^{78}$

\section{Summation}

The above analyzis hints that one should not read too much into the concept of "exceptional circumstances". The theory of exceptionalism lacks substance. Several versions of it co-exist in the case-law. The classic one, elaborated in Magill and IMS Health, applies to refusal to license cases. A stricter version applies in IP remedies cases, like Protégé International. And as an exception to this, an even loser version governs IP remedies cases like Huaweï $v$ ZTE.

Besides, the theory of exceptionalism has not cross-fertilized the Article 101 TFEU case-law. ${ }^{79}$

expanded to cover an array of situations and that the conditions set by the ECJ in IMS/NDC Health do not effectively limit the scope of liability under Article 102 TFEU".

76 See CJEU, IMS Health, supra note 49, §38: "in order for the refusal by an undertaking which owns a copyright to give access to a product or service indispensable for carrying on a particular business to be treated as abusive, it is sufficient that three cumulative conditions be satisfied [...]".

${ }^{77}$ See GC, Microsoft I, supra note 52, §336.

${ }^{78} I d ., \S 665$.

${ }^{79}$ We note here for the sake of exhaustiveness that there is a risk of inconsistency in the case-law if it is one day held that exceptionalism does not apply in Article 101 TFEU. It is widely admitted that a core social function of IP rights is to enable technology dissemination. One thus fails to grasp why "exceptionalism", which seems predicated on 
With all this, the theory of exceptionalism seems again to be less of a theory than a semantical device, used by the Court to convince readers of its judgments (and maybe itself?) that it is not an antitrust activist.

\section{Is Exceptionalism a Pro or Anti-IP doctrine?}

In the scholarship, there seems to be a consensus that the theory of exceptionalism is protective of IPR owners. ${ }^{80}$ Within the IPR community, Vaver writes that the use of concepts like "exceptions" is skewed towards IPR owners, because it treats what "IP owners can do as rights" and "what everyone else can do as indulgences, aberrations from some preordained norm, activities to be narrowly construed and not extended". ${ }^{81}$ Similarly, in the competition community, Anderman and Schmidt stress that the "exceptional circumstances" test "represents an important acceptance by competition law that IPRs are not the same as all other forms of property rights" and "corollary proposition that the "normal' exercise of IPRs will not abuse a dominant position". 82 Lastly, seasoned antitrust economists seem to consider that "exceptional circumstances" constitute an optimal legal standard that adequately protects IPR owners and socially beneficial investments. ${ }^{83}$

the idea of observing deference vis a vis IP rights' social functions, and in particular rewards theory, does not equally apply when what is in question is the other social function of IP rights, namely technology dissemination. This unfathomable discrepancy suggests the CJEU's absence of interest for theological considerations in relation to IPRs. Future cases may offer opportunities for the CJEU to elaborate on the issue, given the wide array of emerging IP contractual relationships giving rise to litigation in national courts, including patent settlements, technology pools and privateering.

${ }^{80}$ Arezzo remarks however that EU competition law remains stricter strict on IP owners than US antitrust law. See Arezzo, E. (2006). Intellectual property rights at the crossroad between monopolization and abuse of dominant position: American and European approaches compared. John Marshall Journal of Computer \& Information Law. $24,455$.

${ }^{81}$ Vaver, D. (2009). Reforming Intellectual Property Law: An Obvious and Not-soobvious Agenda. Intellectual Property Quarterly, 2:143-16, at p.159.

${ }^{82}$ Anderman and Schmidt (2007) supra note 60, at p.107. In the introductory chapter to his book, Anderman explains that exceptionalism is a comity principle which seeks to govern the external regulation of IP law by competition law. He then notes that the trend in EU law is to favour wider IP protection. See Anderman, S. (2007) The Competition Law/IP Interface: An Introductory Note, in Anderman, S. (ed), The Interface between Intellectual Property Rights and Competition Policy, Cambridge University Press, p.2.

${ }^{83}$ Ahlborn et al. (2004) supra note 5, at p.1155: "we have shown that this analogous approach of high, albeit different, hurdles for compulsory licensing by American and European courts constitutes sound competition policy, as it implements the optimal legal standard for assessing refusals to license - one that maximizes long run consumer welfare by minimizing the expected cost of errors resulting from condemning welfare-increasing 
This, however, is an illusion. A quick look at the case-law shows that exceptionalism has entitled the Commission and the Courts to affirm antitrust liability in cases where inherency theory would have commanded a finding of antitrust immunity. In Magill, the EU courts applied the exceptionalism framework and concluded to the existence of an unlawful abuse. ${ }^{84}$ In contrast, the application of inherency concepts like "specific subject matter" and "essential function" vindicated by Advocate General Gulmann would have led to exonerate the TV channels from antitrust liability for their conduct remained within the scope of copyright protection. $^{85}$

\section{COMPLEMENTARITY}

In 2004, the EU Commission introduced a novel idea in soft law instruments: that antitrust and IPR policies share complementary goals. ${ }^{86}$ Without more qualifications, this idea means that competition law can apply with full force to IPR conduct. Pushed to the extreme, virtually any ex post antitrust intervention into IPR strategies is legitimate.

In this section, we expose (A) the source of the theory of complementarity, and proceed to evaluate if it is borne out by the case-law of the CJEU (B).

\section{A. Exposition}

In 2004, a new theory of complementarity was introduced in a soft law instrument of the EU Commission entitled "Guidelines on Technology

practices and from condoning welfare-reducing ones."

${ }^{84}$ In 2008, four years after the judgment, the IMS Health case had not been decided by the National Court. See Rodger, B. (2008) Article 234 and Competition Law: An Analysis, Kluwer Law International, at p.376.

${ }^{85}$ We thus share the reading of Professor Drexl who notes that IMS Health, the Court "is prepared to apply Article $82 \mathrm{EC}$ with the effect of controlling the use of a given right within its scope of exclusivity". See Drexl, J. Is there a more economic approach to intellectual property and competition law, in Drexl, J (Ed.), (2010), Research handbook on Intellectual property and Competition law. Edward Elgar Publishing, at p.37. See Czapracka (2009), p.98 who observes that under this case-law, "competition concerns are given priority over the need to maintain effective protection of IP rights". Yet Czapracka also notes that before Magill and IMS Health, "The specific subject matter and existencelexercise theories have never been much of a safe harbor for IP owners".

${ }^{86}$ Czapracka (2009) id. at p.37 stresses that this idea can be traced back to the works of Bowman, W. (1973). Patent and Antitrust Law: A Legal and Economic Appraisal, Chicago: University of Chicago Press. 
Transfer Agreements" ${ }^{87}$ Pursuant to this theory, which has been reproduced verbatim in the latest update of the Guidelines in 2014:

"[B]oth bodies of law share the same basic objective of promoting consumer welfare and an efficient allocation of resources. Innovation constitutes an essential and dynamic component of an open and competitive market economy. Intellectual property rights promote dynamic competition by encouraging undertakings to invest in developing new or improved products and processes. So does competition by putting pressure on undertakings to innovate. Therefore, both intellectual property rights and competition are necessary to promote innovation and ensure a competitive exploitation thereof". ${ }^{88}$

The introduction of this new theory seems to pair with an implicit rejection of the theory of exceptionalism. The Guidelines nowhere refer to "exceptional circumstances". Neither do they mention the protective inherency concepts adumbrated in prior case-law. ${ }^{89}$

Drexl offers the following reading of the 2004 Guidelines: in his view they "refe[r] to a concept of complementarity of the two fields of intellectual property law and competition law". ${ }^{0}$

At the operational level, the Guidelines' theory of complementarity entails that IPR agreements must be scrutinized pursuant to Article 101 TFEU under a "balancing" approach. ${ }^{91}$ The idea is to weigh the private interest of safeguarding IPR owners' freedom against the public interest of protecting undistorted competition.

Moreover, the Commission's interpretation of the public interest is not limited to undistorted competition, but seems instead to be open-ended one. In relation to non-challenge clauses, the Commission suggests that eradicating weak IPRs belongs to the public interest protected by the competition rules: "The public interest of strengthening the incentive of the licensor to license out by not being forced to continue dealing with a

${ }^{87}$ Drexl and Anderman nonetheless follow this approach.

${ }^{88} 2004$ Commission Notice - Guidelines on the application of Article 81 of the EC Treaty to technology transfer agreement, 2004/C 101/02, §7; See also, §7 of the 2014 Guidelines on the application of Article 101 of the Treaty on the Functioning of the European Union to technology transfer agreements, 2014/C 89/03.

${ }^{89}$ Their sole concession to IPR strategies is seem merely to concede in passing that "[t]he great majority of licence agreements are therefore compatible with Article 101". Guidelines, 2014/C 89/03, supra note 88, $\$ 9$.

${ }^{90}$ See Drexl (2008) op. cit. supra note 85, at p.53.

${ }^{91}$ See Opinion of AG Tizzano in Case 418/01, IMS Health, ECLI:EU:C:2003:537, which describes the balancing test at $\$ 62$ : "weighing the balance between the interest in protection of the intellectual property right and the economic freedom of its owner, on the one hand, and the interest in protection of free competition". 
licensee that challenges the very subject matter of the licence agreement has to be balanced against the public interest to eliminate any obstacle to economic activity which may arise where an intellectual property right was granted in error". ${ }^{92}$

With all this, it is obvious that the theory of complementarity is less deferent to the interests of IPR owners than the theory of exceptionalism that prevails under Article 102 TFEU. Drexl, who seems wary of excessive IPR protection advocates that "The Commission would be well advised to extend its concept of complementary goals of IP law and competition law from the field of technology transfer agreements to the area of abuse of dominance (Article 82 EC) and merger control". ${ }^{93}$

\section{B. Evaluation}

The theory of complementarity has made forays into the Court's contemporary case-law. ${ }^{94}$ Scarlett Extended - a non-antitrust case occasionally mentioned in EU Commission decisions as supportive authority for its enforcement initiatives $-{ }^{95}$ suggests that a degree of balancing is appropriate between the private interest of IP owners and the freedom of third parties to conduct their own business: "The protection of the right to intellectual property is indeed enshrined in Article 17(2) of the Charter of Fundamental Rights of the European Union ('the Charter'). There is, however, nothing whatsoever in the wording of that provision or in the Court's case-law to suggest that that right is inviolable and must for that reason be absolutely protected". ${ }^{96}$

Even more clearly, the Court of justice has seemed to endorse the theory of complementarity in its 2015 judgment in Huaweï v ZTE, holding that the "Court must strike a balance between maintaining free competition - in respect of which primary law and, in particular, Article 102 TFEU and the requirement to safeguard that proprietor's intellectual-property rights and its right to effective judicial protection guaranteed by Article 17(2) and Article 47 of the Charter" ${ }^{97}$

Besides those judicial pronouncements, the theory of complementarity

${ }^{92}$ Guidelines, 2014/C 89/03, supra note 88, §138.

${ }^{93}$ See Drexl (2008) op. cit. supra note 85, at p.53.

${ }^{94}$ We mean the case-law issued since the beginning of the modern era.

${ }^{95}$ See Commission Decision, Case AT.39939 - Samsung C(2014) 2891, (29.04.2014), at footnote 44 .

${ }^{96}$ See Case C-70/10, Scarlet Extended, ECLI:EU:C:2011:771, §43; See also C-360/10 SABAM, ECLI:EU:C:2012:85, §41.

${ }^{97}$ See CJEU, Huaweï v ZTE supra, note $69, \S 42$. 
seems particularly popular with antitrust enforcers. On the conference circuit, agency officials in charge of selling antitrust policy routinely use it to appease critiques of antitrust dogmatism. ${ }^{98}$

If anything, this emerging case-law suggests that Commission's soft law instruments can progressively be given legal force through judicial endorsement. However, the nature of the complementarity relationship that governs the antitrust and IP intersection is left entirely open by the Court of Justice. The CJEU case-law does not specify the weight to be respectively ascribed to the antitrust and IPR variables in the balancing equation. Therefore, the theory of complementarity says nothing more than that antitrust law can apply to IP rights.

More generally, we would like to stress that in a relationship of complementarity, components can and do generally occupy distinct hierarchical positions. To take a graphic analogy, ethologists often explain that complementary species in a same ecosystem occupy high and low places in the food chain, the lion and the antelope being a perfect example. With this background, in Huaweï $v$ ZTE, the Court has ordered the competition and IP variables in a way that suggests that property and judicial rights may occupy a higher position than antitrust protection. The operative part of the judgment, which sets out a safe harbour to patent owners willing to avoid antitrust liability, clearly confirms this reading. ${ }^{99}$

Last, we note that the theory of complementarity has not been introduced in the legislative instrument that the Guidelines purport to accompany, namely the Block Exemption Regulation on technology transfer agreements. ${ }^{100}$ This silence may be interpreted as a sign of the lawmakers' discomfort with the theory of complementarity.

\footnotetext{
${ }^{98}$ See, for an example, J. Almunia speech, IP Summit 2013 (Paris), 9 December 2013: "In their different ways, both the patent system and the system that enforces competition law in the EU pursue common goals. A well-functioning IPR system can in fact promote competition by encouraging firms to invest in innovation. And both competition policy and the intellectual-property protection system do contribute to create the right framework for innovators".

${ }^{99}$ Rato, M. and English, M. An Assessment of Injunctions, Patents, and Standards Following the Court of Justice's Huawei/ZTE Ruling. (2015). Journal of European Competition Law \& Practice. The Huaweï $\mathrm{v}$ ZTE is predominantly a conservative judgment, about antitrust immunity. See Petit, N. (2015). Huaweï v ZTE: Judicial Conservatism at the Antitrust-IP Intersection. CPI Antitrust Chronicle October 2015 (2).

${ }^{100}$ Commission Regulation (EU) No 316/2014 of 21 March 2014 on the application of Article 101(3) of the Treaty on the Functioning of the European Union to categories of technology transfer agreements, $O J$ L 93, 28.3.2014, p. 17-23.
} 


\section{REJECTED THEORIES}

In a 2010 paper on compulsory licensing, Temple Lang noted that "the law has developed piecemeal without any explicit framework or general principle". ${ }^{101}$ His paper, which ambitioned to cure this defect, advanced the proposition that IPR conduct should never be deemed unlawful in itself, unless it is accompanied by an "additional abusive conduct".

We reproduce hereafter his own words: "[i]t cannot be illegal for even a dominant company to use intellectual property rights as they are designed to be used". Instead, "[t]he Court has said that an additional rule applies in the case of intellectual property rights. When a licence of an intellectual property right is asked for, the refusal to licence is unlawful only if there is some other "additional abusive conduct", as well as the refusal to licence". ${ }^{102}$

Of course, the outstanding issue is to understand "what kind of "additional abuse" is required, or how it must be linked to the refusal to contract". ${ }^{103}$ Temple Lang advances the hypothesis that a refusal to license except on excessive royalty terms could constitute "additional abusive conduct" arousing Article 102 TFEU liability.

According to Temple Lang, the source of the "additional abusive conduct" requirement is the Court judgment in $A B$ Volvo and Erik Veng.

On careful consideration, this reading of the case-law seems, however, doubtful. In $A B$ Volvo and Erik Veng, the Court simply held that the exercise of an exclusive right may be caught by Article 102 TFEU if "certain abusive conduct" is present. In our view, the element of "additional" abuse thus constitutes a misleading extrapolation. Nowhere does it appear in the judgment.

Another possible critique is that the Court's ruling seems to say something slightly different than what Temple Lang argues in his paper. In essence, the Court notes that the exclusive prerogatives attached to IPRs can blossom into several types of anticompetitive abuses (eg, outright refusal to license, excessive licensing conditions, etc.). In the Court's view, IPR conduct and antitrust abuse are one and a same thing, and there is no need for additional conduct to trigger the prohibition rule of Article 102 TFEU.

\section{The Rule-BASED APPROACH}

\footnotetext{
${ }^{101}$ John Temple Lang (2010) supra note 13, p. 411.

${ }^{102}$ Id., p.422.

${ }^{103} I d$., p.423.
} 
We now approach the main finding of our paper. In our view, the most noteworthy feature of the CJEU case-law on the antitrust-IP intersection is methodological, not substantive. In almost all cases, the CJEU promotes a rule-based approach, instead of a standards-based approach (A). ${ }^{104}$ Given, however, that this case-law has essentially developed under Article 102 TFEU, an open question is whether a rule based approach also prevails under Article 101 TFEU. Notwithstanding the fact that the CJEU's pronouncements in that field are rarer, there is credence to the argument that Article 101 TFEU cases are also scrutinized under a rule-based approach (B). In our opinion, the CJEU's systemic commitment to a rule-based approach in such cases denotes a plausible concern that discretionary antitrust intervention against IPRs on the basis of post hoc standards would send adverse signals to IPR owners, and disincentivize the production of socially beneficial innovation $(\mathrm{C})$.

\section{A. Rule-Based Approach in Abuse of Dominance Cases involving IPRs}

\section{Hypothesis}

Crane defines rules as "specifications of liability criteria in formal, seemingly precise, and usually short directives". ${ }^{105}$ And Posner writes that a rule "singles out one or a few facts and makes it $r$ them legally determinative". ${ }^{106}$ In essence, a rule-based approach entails the ex ante setting of structured tests of liability. A plain example is a legal command declaring that it is unlawful to "driv[e] in excess of 55 miles per hour on expressways". 107

By contrast, a standard-based approach consists in a flexible resolution of each case on grounds of "open ended, multi-factor and post hoc" considerations such as reasonableness, consumer welfare, competition on the merits, efficiency, fairness, equity, etc. ${ }^{108}$ A plain example is a statute that bans "driving at an excessive speed on expressways". ${ }^{109}$

Rules can be found piecemeal across various areas of EU competition law. The justifiability segment found in Article 101 paragraph 3 TFEU is 14.

${ }^{104}$ For the difference between rules and standards, see Kaplow, L. (1992) supra, note

${ }^{105}$ Crane, D. A. (2007). Rules Versus Standards in Antitrust Adjudication. Washington \& Lee Law Review, 64(1): 49-110, at p. 55.

${ }^{106}$ Posner, R. (2001) supra at p.39.

${ }^{107}$ Kaplow, L. (1992) supra note 14.

${ }^{108}$ Crane, D. (2007) supra note 105, p. 57.

${ }^{109}$ Kaplow L. (1992) supra note 14. 
a good illustration of a rule-based system. A four-pronged test must be met to trigger the benefit of an exemption. ${ }^{110}$ In Article 102 TFEU, predatory pricing is subject to a rule-based approach. The $A K Z O$ case-law holds that prices below average variable costs are presumptively abusive, while prices above average total costs are presumptively lawful. ${ }^{111}$ Finally, rules can also be encountered in merger law. The Airtours judgment requires the fulfillment of three cumulative conditions for the assessment of coordinated effects. ${ }^{112}$

\section{Verification}

In this section, we show that the Court has conventionally followed a rule-based approach in the various categories of cases submitted to its scrutiny.

a. Refusal to license IPRs

Refusal to license cases clearly carry the point, though with a somewhat convoluted history. In $A B$ Volvo and Erik Veng, the Court initially embraced a standard-based approach which left entirely open the conditions under which it could be deemed abusive for an IPR holder to refuse to license its technology. This judicial policy was abandoned in Magill, when the Court promulgated the "exceptional circumstances" rule whereby a refusal to license is abusive if it prevents "the appearance of a new product"; without justification; and this "reserves for [the dominant

\footnotetext{
${ }^{110}$ See Consolidated version of the Treaty on European Union and the Treaty on the Functioning of the European Union, 2012/C 326/01, Article 101(3): "The provisions of paragraph 1 may, however, be declared inapplicable in the case of: - any agreement or category of agreements between undertakings, any decision or category of decisions by associations of undertakings, any concerted practice or category of concerted practices, which [1] contributes to improving the production or distribution of goods or to promoting technical or economic progress, [2] while allowing consumers a fair share of the resulting benefit, and which does not: [3] impose on the undertakings concerned restrictions which are not indispensable to the attainment of these objectives; [4] afford such undertakings the possibility of eliminating competition in respect of a substantial part of the products in question." A possible formal objection to our analyzis is, however, that each of those four prongs enshrine a standard to some extent. Inevitably, however, the boundary between a rule and a standard seems to be a fluctuating one.

111 CJEU, C-62/86, AKZO v Commission, ECLI:EU:C:1991:286, §§71-72: “Prices below average variable costs (that is to say, those which vary depending on the quantities produced) by means of which a dominant undertaking seeks to eliminate a competitor must be regarded as abusive." "Moreover, prices below average total costs, that is to say, fixed costs plus variable costs, but above average variable costs, must be regarded as abusive if they are determined as part of a plan for eliminating a competitor."

${ }^{112}$ GC, T-342/99, Airtours, ECLI:EU:T:2002:146, §§159 and 210.
} 
firm] the secondary market and exclu[des] all competition on that market". ${ }^{113}$

Magill was not, however, the end of the story. In IMS Health, the next compulsory licensing case to reach the CJEU, a "serious dispute" occurred on whether the satisfaction of either of the Magill circumstances was sufficient to affirm liability pursuant to Article 102 TFEU. ${ }^{114}$ The IMS Health Court resolved the issue, holding all three conditions to be cumulative, and not alternative. ${ }^{115}$

Interestingly, the rule-based approach in compulsory licensing cases was not instantly sustained by the General Court. In Microsoft, the GC used a standard-based approach to review the Commission decision that had declared the dominant OS maker guilty of unlawful refusal to supply interoperability information. The judgment found that Microsoft's conduct ran counter to the abstract wording of Article $102 \mathrm{~b}$ ) TFEU which talks of a "limitation [of] technical development". ${ }^{116}$ As was previously argued, the Commission's decision did not meet the requirements of the Magill/IMS Health rule, and especially the "new product" and elimination of "all competition" conditions. The General Court held that this did not matter, for the Commission had met the "limitation of technical development" standard.

In 2012, the General Court nevertheless operated a spectacular U-turn. In Microsoft II - a case about the remedial consequences of the Commission's infringement decision - the General Court no longer talked

${ }^{113}$ CJEU, RTE and ITP, supra, note 43, $§ 52-56$.

114 Case T-184/01 R, Order of the President of the Court of First Instance, ECLI:EU:T:2001:259, §100. See Derclaye, E. (2004). The IMS health decision and the reconciliation of copyright and competition law. European Law Review, 29(5): 687-697, who had early concluded that the conditions were cumulative.

${ }^{115}$ CJEU, IMS Health, supra note 51, §38: "It is sufficient that three cumulative conditions be satisfied, namely, that that refusal is preventing the emergence of a new product for which there is a potential consumer demand, that it is unjustified and such as to exclude any competition on a secondary market". This issue had been a bone of contention in previous proceedings between the Commission and the defendant. The GC remarked in this respect that:

116 GC, Microsoft I, supra, note 52, §647: "The circumstance relating to the appearance of a new product, as envisaged in Magill and IMS Health, cited in paragraph 107 above, cannot be the only parameter which determines whether a refusal to license an intellectual property right is capable of causing prejudice to consumers within the meaning of Article 82(b) EC. As that provision states, such prejudice may arise where there is a limitation not only of production or markets, but also of technical development". See also, §653: "Nor is it necessary to demonstrate that all competition on the market would be eliminated. What matters, for the purpose of establishing an infringement of Article 82 EC, is that the refusal at issue is liable to, or is likely to, eliminate all effective competition on the market". 
to the "limitation of technical development" standard. In an obiter dictum, the GC explicitly refers to the "three cumulative conditions" of IMS Health as the test applicable to refusals to license IPRs. ${ }^{117}$

b. IPR remedy cases (1)

IPR remedy cases have also been dealt with under a rule-based approach. While there is no CJEU case-law on this, the judgment of the General Court in Protégé International held that a finding of abuse can only occur in "wholly exceptional circumstances", and this requires the showing of two conditions: "the action (i) cannot reasonably be considered as an attempt to establish the rights of the undertaking concerned and can therefore only serve to harass the opposite party; and (ii) it is conceived in the framework of a plan whose goal is to eliminate competition". ${ }^{118}$ Those conditions are cumulative and sequential: the second condition is only examined if the first condition is satisfied. ${ }^{119}$ And given the fundamental right of access to court, the two conditions "must be construed and applied strictly". ${ }^{120}$

c. IPR remedy cases (2)

The CJEU endorsed again a rule based approach in cases in which owners of FRAND-pledged SEPs had sought injunctions against unlicensed implementers of their technology.

In Huaweï $v$ ZTE, the Court held that antitrust liability could be affirmed against IPR owners enforcement actions in the presence of two particular circumstances. First, the "patent at issue is essential to a standard established by a standardisation body". ${ }^{121}$ Second, "the patent at issue obtained SEP status only in return for the proprietor's irrevocable undertaking, given to the standardisation body in question, that it is prepared to grant licences on FRAND terms". ${ }^{122}$ According to the Court, such conditions create "legitimate expectations on the part of third parties" that holders of FRAND pledged SEPs will openly license their technology. ${ }^{123}$

Closely related to this is the fact that Huaweï $v$ ZTE also sets a rule of exoneration, besides the liability rule. The Huaweï $v$ ZTE court explains

\footnotetext{
${ }^{117} \mathrm{GC}$, Microsoft II, supra, note 52, $\$ 139$

${ }^{118}$ Ibid, \$ 49.

${ }^{119}$ Ibid., § 49.

${ }^{120}$ Ibid., $\S 49$.

${ }^{121}$ Ibid., § 49.

${ }^{122}$ Ibid, $\$ 51$.

${ }^{123}$ Ibid., \$53.
} 
the conditions under which a dominant FRAND-pledged SEP holder that applies for an injunction can avoid a finding of abuse. ${ }^{124}$ First, the patent owner must "alert the alleged infringer of the infringement complained about by designating that SEP and specifying the way in which it has been infringed". ${ }^{125}$ Second, the patent owner must "present to that alleged infringer a specific, written offer for a licence on FRAND terms, in accordance with the undertaking given to the standardisation body, specifying, in particular, the amount of the royalty and the way in which that royalty is to be calculated". ${ }^{126}$ Third, at each stage, the patent owner must leave to the implementing infringer a sufficient time to react declaration of willingness to transact, acquiescence or counter-offer prior to contemplating the seeking of a court injunction. If the patent owner complies with those procedural "conditions", he "does not abuse its dominant position ... by bringing an action for infringement". ${ }^{127}$

d. Pricing (and terms) of IPR licenses

The $D S D$ judgment is also rule-based, though less explicitly. The Grand Chamber of the CJEU upheld the GC and the Commission decisions on the ground that they had correctly applied the rule set in the case-law on unfair pricing. As the Court recalls, a firm "abuses its dominant position where it charges for its services fees which are disproportionate to the economic value of the service provided", a finding that is not left to full agency discretion, but that must be established by reference to price-cost metrics. ${ }^{128}$ On the facts, the CJEU seemed satisfied that the Commission had carried out - though in a crude way - the pricecost rule required for exploitative abuses cases. ${ }^{129}$

${ }^{124}$ The reasoning of the CJEU could not be less clear. At $\$ 55$, the Court talks about how "the proprietor of an SEP" can "prevent an action for a prohibitory injunction or for the recall of products from being regarded as abusive."

${ }^{125} I d ., \$ 61$.

${ }^{126} I d ., \S 63$.

${ }^{127} I d ., \$ 71$.

${ }^{128}$ CJEU, DSD, supra note 63, §142; GC, T-151/01, Duales System Deutschland v Commission, ECLI:EU:T:2007:154 §121.

${ }^{129}$ Commission Decision 2001/463/EC of 20 April 2001, Case COMP D3/34.493 DSD, OJ $2001 \mathrm{~L} 166$, p. 1, §111. The Commission held in particular that DSD had abusively used its trademark right to charge prices on clients regardless of whether they made use of its waste collection services. The Commission objected to this because: "Although DSD makes payment of the licence fee contractually dependent on the use of the mark, the costs which arise for DSD are based on the extent to which the other party actually makes use of the exemption service”. 


\section{B. Rule-Based Approach in Coordinated Conduct Cases?}

If it is true that the CJEU follows a rule-based approach in antitrust cases with IP ramifications, then one should expect to observe it also in the Article 101 TFEU case-law. Unfortunately, however, no such showing can be made. For the reasons previously explained, the CJEU has produced little case-law on the intersection between Article 101 TFEU and IPRs. Until new cases are brought to the Court, this question will remain unresolved.

This notwithstanding, the submission of this paper is that the CJEU needs not (or less) introduce judge-made "rules" in its Article 101 TFEU case-law for the simple reason that such rules are already hard wired in the wording of Article 101 TFEU. Unlike Article 102 TFEU, the letter of Article 101 TFEU imposes a very structured process and several substantive conditions before a finding of liability can be attained. The first paragraph of Article 101 TFEU imposes the characterization of an "agreement", and a showing of anticompetitive impact by "object" or "effect". The demonstration of anticompetitive effect, in turn requires proof of an adverse, plausible and appreciable impact on competition. If all those conditions are met, the third paragraph of Article 101 TFEU then gives defendants an opportunity to rebut antitrust liability if they bring proof of four cumulative conditions, namely that their agreement (i) "promo[tes] the production or distribution of goods or to promoting technical or economic progress"; (ii) "allow[s] consumers a fair share of the resulting benefit"; (iii) does not impose "restrictions which are not indispensable"; and does not lead to the "possibility of eliminating competition".

By design, Article 101 TFEU cases thus enshrine a rule-based approach.

In addition to this, the scant case-law on the antitrust-IP intersection under Article 101 TFEU whispers adherence to the rule-based framework. To start, let us look at one contemporary case where the CJEU was invited to move away from the rule-based framework of the Treaty, and embrace a standard-based approach. In GSK $v$ Commission, the pharmaceutical company GSK had been found guilty of a restriction of competition by object on the ground that it had applied a system of dual pricing which penalized Spanish buyers who engaged in parallel exports. On appeal, the General Court considered that the existence of a restriction by object had to be characterized by recourse to a standard, namely 
consumer harm. ${ }^{130}$

On further appeal, the CJEU vacated the GC judgment. It noted that "neither the wording of Article [101(1) TFEU nor the case-law lend support to such a position", and that the GC had committed an error of law by "requiring proof that the agreement entails disadvantages for final consumers as a prerequisite for a finding of anti-competitive object". ${ }^{131}$ What seemed to drive the Court's analyzis is the imperative of sticking to the clear text of the Treaty: "there is nothing in that provision to indicate that only those agreements which deprive consumers of certain advantages may have an anti-competitive object (emphasis added)". ${ }^{132}$

In all events, many older judgments of the Court at the antitrust-IP intersection suggest a commitment to a rule-based approach in Article 101 TFEU cases. This is true of the case-law on territorial restrictions in licensing agreements, where the Court has affirmed a per se prohibition rule. The scope of this per se rule is often confusingly presented as a blanket and prohibition of all licensing restrictions which limit "parallel trade" in the EU. This reading is wrong. The Court's judgments set out a structured liability test which only apprehends a subset of licensing restrictions that exhibit certain features. Those conditions are the following: (1) the licensing restrictions must compartmentalize national markets, by opposition to licensing restrictions that insulate regional or local markets; ${ }^{133}$ (2) the licensing restrictions must provide "absolute" protection to the licensee on a national territory, and not any kind of protection from competitive imports.

Let us sift through the main cases. The per se prohibition rule was affirmed in Consten and Grundig $v$ Commission. As previously explained, Grundig, a manufacturer of radio receivers, recorders, dictaphones and television sets, had granted exclusive territorial protection to Consten for the distribution of its products in France. Under the contract, Consten would be prohibited to actively and passively export machines outside the contract area, and Grundig had imposed a similar prohibition on its sole distributors in other countries and on its German wholesalers. Moreover,

\footnotetext{
${ }^{130}$ Consumer harm can be deemed a standard, because it is abstract, flexible and multifactor (price, quality, choice, etc.). The GC seemed to consider that parallel traders often pocket in the price difference, so that consumer harm is far from obvious.

${ }^{131}$ CJEU, C-501/06 P, C-513/06 P, C-515/06 P and C-519/06 P, GSK v Commission, ECLI:EU:C:2009:610, §§62-64.

${ }^{132} I d ., \S 63$.

${ }^{133}$ In other words, the CJEU case-law only affirms a per se prohibition of licensing restrictions, upon the showing of a separation of national markets, and not for licensing restrictions between the EU and third countries or for licensing restrictions within to an EU Member State.
} 
Grundig would not sell machines to other distributors in France. On appeal, the CJEU confirmed the existence of an infringement, noting that the arrangement gave rise to "absolute territorial protection" and resulted in the "isolation of the French market".

Since then, Consten and Grundig has been repeated on many occasions, and in relation to a variety of IPRs. To take a few examples, in Nungesser and Eisele, the French National Institute for Agricultural Research ("INRA") had licensed breeders rights over maize seeds to a supplier of seeds in Germany. The licensing agreement provided that INRA would refrain from issuing other licenses in Germany and from supplying seeds itself in Germany. Moreover, there was a contractual commitment by INRA and the licensee to use all possible means to ensure that third parties would not import from other Member States into Germany, and from Germany towards other Member States. When parallel importers introduced INRA seeds for sale to German buyers, INRA sought to exert pressures and commenced legal proceedings. The dispute was finally resolved by the Court, which held that: "absolute territorial protection granted to a licensee in order to enable parallel imports to be controlled and prevented results in the artificial maintenance of separate national markets, contrary to the Treaty". ${ }^{134}$

Last, in Football Association Premier League Ltd. (FAPL), the Court was questioned on the legality of the exclusive licensing agreements between FAPL and a number of national broadcasters over Europe. Those agreements included a general obligation on each national broadcaster to ensure that broadcasts could not be "received outside that territory" and of a specific "prohibition from supplying decoding devices that allow their broadcasts to be decrypted ... outside the territory". ${ }^{135}$ Though not strictly about copyright, the case shocked the European broadcasting industry because the Court affirmed in that: "an agreement which might tend to restore the divisions between national markets is liable to frustrate the Treaty's objective of achieving the integration of those markets" and "must be regarded, in principle, as agreements whose object is to restrict competition (emphasis added)".

Clearly, the wording of those judgments bespeaks a per se prohibition rule against licensing restrictions which create "export bans", "partition national markets", and give ultimately rise to "absolute territorial protection". The Court's case-law, by contrast, does not endorse a loose,

\footnotetext{
${ }^{134}$ CJEU, C-258/78, Nungesser v Commission, ECLI:EU:C:1982:211, §61.

${ }^{135}$ CJEU, C-403/08 and C-429/08, Football Association Premier League Ltd. (FAPL), ECLI:EU:C:2011:631, §35.
} 
abstract and general standard like the limitation, distortion or restriction of parallel trade.

To close, we observe that a rule based approach seems also to prevail in relation to arguments made by defendants willing to redeem anticompetitive licensing restrictions. Ottung and Bayer AG v Sullhofer provide two possible illustrations. Whilst the Court admitted that some licensing clauses could be dealt with under a standards approach (the Court pointed out to an analyzis of the "economic and legal context"), both judgments are essentially known for the rule of immunity, and the accompanying structured test, set out in relation to certain anticompetitive licensing restrictions. In Ottung, the Court considered that an obligation to pay royalty for an indeterminate period that possibly extends beyond patent expiry was per se lawful, as long as the licensee kept the ability to terminate the licensing agreement by giving reasonable notice. ${ }^{136}$ This rule of legality was recently recalled by Advocate General Wathelet in his Opinion in Genentech Inc. v Hoechst GmBH. ${ }^{137}$ In Bayer AG v Sullhofer, the Court ruled that non challenge clauses fall short of Article 101(1) TFEU when the agreement provides for a free license or relates to an outdated process that the licensee did not use. ${ }^{138}$

Even more clearly, the judgment in Erauw Jacquery $v$ La Hesbignonne conveys a rule based approach. ${ }^{139}$ Here, the CJEU held that liability for absolute territorial protection can be eschewed if this is needed to protect (i) a supplier who has incurred "considerable financial commitment"; (ii)

${ }^{136}$ CJEU, 382/87, Kai Ottung $v$ Klee \& Weilbach $A / S$ and Thomas Schmidt $A / S$, ECLI:EU:C:1989:195, §13.

${ }^{137}$ Opinion of AG Wathelet in C-567/14, Genentech Inc. v Hoechst GmBH, not yet published (proposing immunity for royalty demands bearing on patents which were subsequently revoked or deemed non infringed).

${ }^{138}$ CJEU, 65/86, Bayer AG and Maschinenfabrik Hennecke GmbH v Heinz Süllhöfer, ECLI:EU:C:1988:448, at $\S \S 17$ and 18.

139 CJEU, 27/87, SPRL Louis Erauw-Jacquery $v$ La Hesbignonne SC., ECLI:EU:C:1988:183, §10. In the past, there was another exception for absolute territorial protection that exonerated agreements devoid of appreciable effects on competition (also known as de minimis agreements). See CJEU, 5/69, Franz Völk v S.P.R.L. Ets J. Vervaecke, ECLI:EU:C:1969:35, §§5-7: “An exclusive dealing agreement, even with absolute territorial protection, may, having regard to the weak position of the persons concerned on the market in the products in question in the area covered by the absolute protection, escape the prohibition laid down in article 85(1 )." However, in Expedia, the CJEU eliminated this exception. It held that "It must therefore be held that an agreement that may affect trade between Member States and that has an anti-competitive object constitutes, by its nature and independently of any concrete effect that it may have, an appreciable restriction on competition". See CJEU, C-226/11, Expedia Inc. v Autorité de la concurrence, ECLI:EU:C:2012:79, §37. 
against risks of “improper handling” of his input. ${ }^{140}$

\section{Rationale for a Rule-Based Approach in Antitrust Cases involving IPRs?}

All readers of EU case-law are familiar with the CJEU longstanding practice of stating what the law is, without articulating why this law is justified. ${ }^{141}$ In the IP field, Korah once talked about the Court's "frequent unwillingness to analyze theoretically, but rather to rule on results". ${ }^{142}$ In this section, we therefore attempt to uncover the intellectual foundations of the rule-based approach.

At an abstract level, there are several explanatory factors for a rulebased approach in antitrust cases with IPR ramifications. Given the perils of ex post rationalization, we decline to choose amongst them.

First, a well-known advantage of structured tests of liability, as opposed to loose standards is their predictability. ${ }^{143}$ In contrast, standards leave more space for discretionary intervention.

With this background, it is conceivable that the Court adheres to the idea that legal uncertainty disincentivizes investments, and that this risk is even more compounded in areas with high IPR density where the strength of intellectual property exert - an indeterminate yet certain - influence on investments into innovation. We join in this respect Regibeau and Rockett who suggest that the adoption of clear rules acts as a remedy against regulatory opportunism into IPRs. ${ }^{144}$

${ }^{140}$ Competition academics tend, however, to relativize the relevance of the ruling. According to Professor Korah and O'Sullivan the judgment delineates a "very narrow exception" due to the specific nature of plant breeders' rights. Talking of a "very narrow exception", due to the specific nature of plant breeders' rights. Korah, V. \& O'Sullivan, D., (2002) Distribution Agreements under the EC Competition Rules, Hart Publishing, at p.82. Ezrachi goes even further. He talks of the "unique circumstances" of the case. See Ezrachi, A., (2014) EU Competition Law: An Analytical Guide to the Leading Cases, Bloomsbury, at p.337.

${ }^{141}$ Something that can be described as "it-is-so-because-we-say-so" jurisprudence, see Webster v. Reproductive Health Servs., 492 U.S. 490, 552 (1989) (Justice Scalia, concurring in part and concurring in the judgment).

${ }^{142}$ Korah, V. (2001), supra note 48 , at p.818.

${ }^{143}$ As Crane notes: "One strong advantage of rules over standards is predictability, which matters most when one is trying to incentivize appropriate behavior". See Crane, D. (2007) supra note 105 , at p.85.

${ }^{144}$ Regibeau, P. \& Rockett, K. (2007) The relationship between intellectual property law and competition law", in Andermans (2007), supra note 8: "A further reason not to allow competition law judges to systematically revisit the trade-offs already considered by (intellectual) property law is what economists refer to as the risk of regulatory 
Second, the rule-based approach may be a signalling device, used to reassure the Member States that the EU will not discretionarily encroach upon their exclusive competence in relation to property rights. As Dreyfus and Liannos argue, the antitrust-IP intersection is shaped "by the division of competence between the EU and its Member States with regard to IP and competition law". ${ }^{45}$

Third, judicial economy considerations may also have exerted influence on the Court's case law. Given the frequency of IPR transactions, the additional cost of designing a rule (which is borne only once) is likely to be lower than the costs of applying a standard on a case by case basis. ${ }^{146}$ The same is true for users of the law (be they competition agencies, national courts, and practitioners) who incur only once the cost of figuring out what the law is, and can then spread this fixed cost over an indefinite number of cases. ${ }^{147}$

Last, the rule-based approach may again be rationalized on the basis of the well-known aversion of the CJEU vis-à-vis the use of economics in the

opportunism. As we saw in part I, once intellectual property is produced (and disclosed), the socially optimal allocation is for every economic agent to have free access to it. In other words, the optimal level of monopoly power ex post is none. As competition law only faces such ex post situations, there might be a strong temptation to limit the use of IPbased monopoly power so much that adequate rewards for investment in IP could no longer be provided. This temptation might even be stronger at the level of individual cases since, as we discussed above, a single case is unlikely to significantly the expected reward on which investors base their decisions. However, succumbing to this temptation would lead to a 'death of a thousand cuts', where the combined effect of apparently innocuous individual case decisions combine to wreck the delicate balance achieved by IP law. The remedy against regulatory opportunism is commitment. In the case of competition law, commitment can only come from the clarity of how the law should be implemented. The clearer the rules, the stronger the commitment. It would therefore be advisable to explicitly state that competition law should respect the rights granted by (intellectual) property law and that the trade-off between static and dynamic efficiency is not a primary concern of competition law. This principle does not prevent the enforcement of (possibly strict) competition laws but it implies that conditions under which the use of monopoly power will be restricted must be as unambiguous as possible. The essential facility doctrine can be seen as a good example of such an approach. On the one hand, it is entirely consistent with the general respect of property rights that we advocate and acknowledges that property rights can only be effective if they do imply some monopoly power. On the other hand, it allows for a clear exception when the monopoly power associated with the property right is so large as to result in an unacceptable loss of welfare".

${ }^{145}$ See Lianos and Dreyfuss (2013) supra note 4, at p.53.

${ }^{146}$ See Kaplow, L. (1992), supra note 14, at p.621: "The central factor influencing the desirability of rules an standards is the frequency with which a law will govern conduct If conduct will be frequent, the additional costs of designing rules-which are borne once-are likely to be exceeded by the savings realized each time the rule is applied".

${ }^{147}$ Id. p. 583 . 
adjudication of cases. As Crane notes, "rules signal a greater importance for lawyers and standards signal a greater role for economists in antitrust adjudication". ${ }^{148}$ And while the Court's distaste of economics in genuine antitrust cases is well-known, its discomfort with the economics of IP seems at least equal. We certainly have no direct proof of this, but some indirect pronouncements provide some evidence. In its case-law, the Court has made many conflicting pronouncements on the relationship between ownership of IPRs and market power. Whilst in Magill, the Court asserted that "[s]o far as dominant position is concerned, it is to be remembered at the outset that mere ownership of an intellectual property right cannot confer such a position", it contradicted itself in Sot Lelos kai Sia EE and Others $v$ GlaxoSmithKline with the formidable - and flawed statement that: "a medicine is protected by a patent which confers a temporary monopoly on its holder". ${ }^{149}$ If anything, the spectacular degree of confusion of the Court on this basic issue strongly suggests a discomfort with the economics of IPRs. ${ }^{150}$

\section{CONCLUSION}

This article has provided a survey of the case-law and of the scholarship on the antitrust-IP intersection. Its main conclusion is that no

${ }^{148}$ Crane, D. (2007) supra note 105, at p.27.

${ }^{149}$ CJEU, C-468/06 to C-478/06, Sot. Lélos kai Sia EE and Others v GlaxoSmithKline AEVE, ECLI:EU:C:2008:504, § 64. A similar analogy between a patent and a monopoly can also be found in the Commission's pleadings in Windsurfing. CJEU, C-108/97 et C109/97, ECLI:EU:C:1999:230, §91: "The Commission, however, takes the view that even where a licensee is only able to challenge a patent because of the information which has become available to him as a result of his privileged relationship with the licensor, the public interest in ensuring an essentially free system of competition and therefore in the removal of a monopoly perhaps wrongly granted to the licensor must prevail over any other consideration".

${ }^{150}$ Other courts have also made baffling statements over the market power that allegedly stems from IP. See GC, T-321/05, AstraZeneca AB and AstraZeneca plc $v$ Commission, ECLI:EU:T:2010:266, §362: "When granted by a public authority, an intellectual property right is normally assumed to be valid and an undertaking's ownership of that right is assumed to be lawful. The mere possession by an undertaking of an exclusive right normally results in keeping competitors away, since public regulations require them to respect that exclusive right". See also the words used by Advocate General Mischo, C-35/87, Thetford/Fiamma, ECLI:EU:C:1988:218, §21: "It is from that point of view that Fiamma's example of the grant of a patent for a perfectly ordinary football may be helpful. If a Member State were in fact to grant a patent for such an article in everyday use, without any doubt its motive would be to reserve a monopoly for a national manufacturer, thereby imposing a disguised restriction on trade within the meaning of the second sentence of Article 36". 
substantive theory drives the relationship between ex ante IPR policy and ex post competition enforcement. Instead, the singularity of the case-law in this field is that the CJEU predominantly approaches antitrust cases with IPR ramifications under a rule-based approach.

This methodological choice certainly has many merits. But it begets a fundamental question: that of the optimal design (content) of the legal rules applicable at the antitrust-IP intersection.

Moreover, when looked at more closely, the rules defined by the CJEU often seem to embed standards. Put differently, the case-law at the antitrust-IP intersection formulates structured tests of liability or justifiability that resort to abstract concepts. For instance, the $D S D$ judgment talks of fees which are "disproportionate" to the economic value of the service. Similarly, the four prong test of Article 101(3) talks of "improving", "fair", "indispensable" or "substantial". Those notions are closer to the excessive speed standard than from the 55 miles per hour rule.

With this qualification, our conclusion ought to be that the Court approaches the antitrust-IP intersection with a rule-based spirit, but when it comes to give content to structured test of liability and justifiability, it resorts to abstract concepts. The implications of this judicial policy are not entirely clear. Does this correct the traditional risks of over and under-inclusion (or both) encountered with rules-based approach? ${ }^{151}$ If this is the case, does this come at the expense of legal certainty?

Future research in this field is needed. As often in antitrust law, the input of economics will surely be of great assistance.

${ }^{151}$ Posner, R. (2001) supra at p.39. 